\title{
The Specter of Neoliberalism: Thanatonomics and the Possibility of Trans-Individualism
}

\author{
Mark Featherstone
}

\section{What is Austerity?}

In this article I want to explore the psycho-politics of austerity in the context of neoliberal capitalism with particular reference to the British case, which I take to be the home of early liberalism and industrial capitalism and the contemporary site of what I want to call neoliberal thanatonomics, or the approach to political economy that mixes unsustainable levels of austerity and poverty with similarly excessive forms of luxury and consumption. Although neoliberal capitalism is considered a political and economic form defined by its utilitarian rationality, pragmatism, and commitment to the bottom line, I want to suggest that this mode of capitalism is also organized around a kind of hyper-moralism, which is ultimately theological in origin and quasi-theological in practice. Given this cultural, quasi-theological, political economy, I suggest that Britain, Europe, and essentially capitalism more broadly, is in the process of sliding back towards a new Victorianism, defined by hyper-division and hyper-inequality. Under these conditions, my thesis is that the current post-crash settlement, which suggests that austerity and hyperinequality is a kind of temporary fix, will quickly become unsustainable. At this point, the neoliberal commitment to the realism of base materialism will begin to tip over in a new political idealism able to recognize the necessity of the social relationship between self and other and the ecological interdependence between self, other, and world that is currently prohibited by a combination of economic realism, post-political individualism, and a broader historical repression of the necessity of being together in the world. However, I suggest that in order to reach this point where the truth of what Gilbert Simondon (Combes, 2012) called trans-individualism can be realized, the left will need to confront and pass through what I explore through the idea of the resistance to social analysis that has resulted from the traumatic breaks of first, modern liberal, and second, post-modern neoliberal capitalism. In order to conclude I argue that this confrontation, and "working through," will ultimately be made possible by the contemporary thanatonomic model of economics which continues to produce unsustainable levels of inequality, austerity, poverty, luxury, and wealth. On this basis of the re-emergence of a new class politics based in a popular recognition of vast inequality and injustice my claim is that the current spirit of neoliberal capitalism that seeks to legitimate division on the basis of the moral superiority of the super-rich will eventually give way to its demonic other, the spectre of neoliberalism, that suggests the possibility of a general economics of social identity, trans-individualism, and what Georges Bataille (1991) wrote about in terms of continuous being. However, before exploring the psycho-politics of thanatonomics and moving beyond this to think through the possibilities of working through the repressive resistance to social analysis, I want to turn to the condition of austerity and then open out onto a broader exploration of the inequality and injustice of contemporary, or what we might correctly call, late capitalism.

Like much of Europe, since 2008, and certainly since 2010, the British social, political, economic, and cultural landscape has been defined by the idea of austerity. In this context austerity refers to a material, economic, condition determined by the logic of the cut. According to this logic, which was the policy motor of the Cameron-Osborne 
Conservative government, public spending must be reduced in the name of a minimal welfare state and what Cameron famously called "the big society" where people effectively live beyond the state and no longer rely on central government to organize their lives. Given this push to reduce state spending and state interference, public institutions, such as the social security state, education, and health, must shrink, and have shrunk, or have been reorganized so that they are more cost effective. The purpose of this drive for efficiency is to purge state-run institutions of non-productive waste. Exposure to the logic of the market is key here because competition ensures that waste and "running in the red" is entirely unsustainable. However, the problem with this austere drive to cut spending is that it appears unsuitable to respond to the economic, never mind social problems caused by the crash and subsequent recession which set in in the wake of the state bank bail outs. As Mark Blyth (2013) notes in his book, Austerity, harsh cuts in state spending cannot produce growth in order to lift an economy out of recession because saving and, beyond this, the investment required to produce growth rely on spending in order to first, generate money which can be saved and second, increase confidence to stimulate investment. For Blyth the policy of austerity is therefore economically utopian in the sense that its core idea is simply unrealistic. In his view the assumption that cuts will balance the books, continue to produce growth, and not produce a spiral of recession and decline is unfounded, unsustainable, and based in a kind of individualized economic common sense.

However, this is not to say that the champions of austerity are naïve because this is clearly not the case and in pointing out their lack of long term economic realism what Blyth tends to underplay in his book is the neoliberal elite's particular brand of political utopianism which relies on an alternative vision of the objectives of economic production. The core idea of this political utopianism, which I would suggest it is possible to observe in the British case, resides in a vision of the reorganization of class society and the construction of a kind of post-modern Victorianism that recalls Disraeli's (2008) idea of the two nations. According to this new neoliberal utopian vision, austerity is absolutely not a temporary fix, concerned to address state over-spend and balance the books in order to create the conditions for sustainable growth and the improvement of living standards across the board, but rather a permanent condition organized around the recognition that growth, spending, and improvement cannot be for everybody, if capitalists are to continue to extract extreme levels of surplus profit from the production process. While Europeans and, in this particular case, the British live with the language of austerity now, it may be the case that this feeling of living under pressure and of not being able to access necessary public goods such as healthcare and education which it is assumed should be available to everybody, will vanish in the austere future when austerity is no longer thought about in terms of a short-term response to crash, recession, and a discourse of state over-spend, but has instead become normalized and entirely accepted by a class society that cannot speak its name or recognize the injustice of hyper-division and hyper-inequality. The first and perhaps critical moment of the implementation of this neoliberal utopian vision in the British case, but also in the European context, came when the financial crash was transformed from a problem generated by the over-leveraging of banks that had adopted a philosophy of riskless risk around securitized lending into a crisis of public spending and the over-reach of the state, and particularly the welfare state, into the lives of its citizens. There is no doubt that state over-reach was, and remains, a problem but this is certainly not an issue around public spending and welfare. On the contrary, this issue of over-reach was and is absolutely concerned with state intervention in, or more accurately the attachment to, the agendas of business and finance concerned with the production of excessive levels of surplus value that never trickle down through the class system.

On the basis of this attachment and identification, Blyth (2013) explains that this first moment of what I am writing about in terms of the neoliberal utopian vision of a new Victorianism entailed the discursive sleight of hand that saw a problem of financial irresponsibility become an issue of public over-spend on apparently unproductive welfare and civic goods, such as health and education. Following this claim, Blyth makes the point that the effect of this discursive sleight of hand was to transfer the cost of the private sector bank bailout, which in the British case amounted to over $f_{140}$ billion, to the public sector that was then required to absorb the cost of this transfer of state funds into private hands. But beyond the short term need to balance the books and absorb the costs of the bail out, it is clear that the crash, crisis, and subsequent recession presented the neoliberal elites with an opportunity to reconstruct social and economic relations and employ the kinds of shock tactics set out by Naomi Klein (2007) in her now classic, The Shock Doctrine, to pursue utopian political ends. In this case the crash, and related discursive transfer of responsibility for financial meltdown from banks to welfare, enabled the neoliberal elite to minimize state responsibility for the welfare of the social body and open up new spaces for private sector investment and ultimately exploitation of a population which, in the British case at least, was largely responsive to the message that the crash, crisis, and recession was the result of state overspend on the undeserving poor. Although the Conservative-Liberal 
Democratic coalition which imposed austerity in Britain from 2010 to 2015 suggested that "belt tightening" was universal and that everybody was part of this exercise, it is hard to miss the class based politics of this apparently purely economic policy. Contrary to the Conservative line that "we're all this together," the political impact of the class based dimension of what we might call uneven austerity in Britain has been to first, drive vast numbers of people (low earners, the unemployed, single parents, the disabled, and the disadvantaged) into poverty making them fit for exploitation by business looking to suppress wages and second, leave the business elites and super rich free to make and spend money with wild abandon.

While there is certainly economic growth in this scenario, this is not the kind of growth imagined by Keynes or Keynesians who ultimately thought that growth and economic expansion should result in improvement in the lives of the population across the board. On the contrary, this is the kind of growth that Marx (1990) observed in the 19th century and associated with the practice of unlimited exploitation that drove the working classes and lower orders into a state of poverty on the very edge of existence. Although it would be hard to sell a policy of uneven austerity, even to the British who understand class inequality in terms of a kind of feudal social contract between bosses and workers, because notions of meritocracy and the right to consume are deep rooted in neoliberal society, the neoliberal elites have sought to justify the logic of the public sector cut through the ordoliberal vision of order and stability. In other words, the basic message of austerity is that the books must be made to balance. In this context Greece has become a symbol of the problem of Keynesian state over-spend, when it is in actual fact a reflection of neoliberal hubris based in normalized corruption, tax evasion, and centrally a belief that there is no end to the wealth that the rich can accumulate in the context of monetary union designed to create a Europe wide frictionless free market. In the wake of the American financial crash, which quickly spread to the Euro zone, it became impossible to manage the Greek debt burden in a situation where monetary union means taking a hit for others, rather than making a profit from their labor, primarily because Greece's EU partners were, and remain, unwilling to support their debtors. As a result, the problem of Greek debt remains, even in the wake of the most recent EU bail out of July, 2015, and it difficult to see how Greece will ever escape a state of indebtedness. While Syriza has sought to defend the right of the Greek people to a decent life, the objective of the Euro zone leaders has been to provide loans to enable the Greeks to repay investors in exchange for the imposition of draconian austerity measures designed to retrofit Greece for a future of neoliberal super-exploitation. In the current political situation, Greece remains a kind of limit case of austerity, and a symbol for the reason austerity must be imposed in a situation where it is impossible to conceive that investors should take a hit in order to avert a socio-economic humanitarian crisis.

The reason it has become unthinkable to write off the Greek debt, and the reason private investment is considered untouchable, is essentially political in the sense that the neoliberal elites stubbornly refuse to consider loses when they can shift responsibility and costs onto the wider social body that they believe should pay for their exorbitant privilege. However, there is also a clear cultural and philosophical history that means that it makes sense to the wider population, especially in the case of Britain which gave birth of liberalism, to reduce state spending and defend private property rights to the very end. It is to this cultural history that I now turn. According to Blyth (2013), the history of austerity starts with John Locke's (2003) work on role of government, which captures the neoliberal ambivalence towards the state that is on the one hand a dangerous institution that costs too much and always threatens the liberty of free men, but on the other hand remains a necessity required to defend private property rights. While this view more or less defines the contemporary neoliberal attitude to the state, which should create the conditions or, in the language of the German ordoliberals, the framework for the market to operate, it also reflects the classical liberal anxiety about state spending and centrally state debt that it is possible to find in the writings of Hume and Smith and that has re-emerged in the wake of the crash. Against Keynes (1965), who thought that the state should organize capitalism in the name of the social body, the contemporary neoliberal vision of the state represents a fusion of the ordoliberal theory concerned with state responsibility for market order and competition and the laissez faire fear of big government and later, in the work of Hayek, the phobia of totalitarianism. From the latter perspective, which is most clearly represented by Hayek's (2001) The Road to Serfdom, it is absolutely essential that the state does not overstep the mark and meddle in the market. In Hayek's view the Keynesian "tax and spend" welfare state was already well on the road to totalitarianism and he did not hold out much hope that this dystopia could ever be averted because the progress towards the all-encompassing Weberian iron cage seemed unstoppable.

While Blyth (2013) starts his history with Locke, the historian Florian Schui (2014) projects the origins of the idea of austerity back further than liberal concerns about the state and public over-spend, and in a sense deepens the idea of the west's cultural attachment to the notion of the austere life. In his view it is possible to trace the history of Smith's idea of frugality back to Greece, Aristotle, and what we might call the body economic where moderation 
is the key to the good life. Although it is hard to understand how this sentiment, which is essentially the cultural progenitor of the theory of economic austerity, survives in the contemporary period characterized by an obsession with consumption and excess, Schui's history shows that Aristotle's vision is deeply embedded in western culture, where it influenced Roman stoicism and the work of Seneca, Christianity where the welfare of the soul requires that the true believer resists the temptations of the flesh that know no limits, through to contemporary populist movements around well-being and happiness in moderation. Indeed, it was only much later in modern Europe, when thinkers such as Hobbes (2008) and Mandeville (1989) began the challenge the wisdom of the ancients, that philosophers and political theorists started to understand the gap between the behavior of the individual and society and recognize that the ancient political psychology of the micro / macrocosm where the individual is a reflection of civic life, which is in turn a reflection of cosmic processes no longer necessarily held. While Hobbes saw that the natural instincts of men needed to be subsumed in the political society of the leviathan able to maintain order, Mandeville explained that private vices could produce public virtue and reached the conclusion that a prosperous society defined by wickedness was in the end a better option than a poor, but virtuous community. But if Mandeville saw the value of or perhaps even good in selfishness, Schui shows how the works of classical liberals such as Smith $(2010,2012)$ and Weber (2010) were essential to move this new macroeconomic theory towards the logic of capital and capitalism, primarily because they recognized that selfish accumulation is in itself not enough to generate economic growth and that what is required is a sense of frugality, abstinence, and a moral commitment to work able to create a tendency to investment and reinvestment.

Thus Schui (2014) explains that both Smith and Weber imagined the moral or virtuous capitalist who made money and invested capital on the basis of theological belief in the basic goodness of hard work and economy. In other words, what they achieved was to square the circle of ancient moderation, balance, and stasis and modern vice, dynamism, and change and show how economic growth was made possible precisely by the austere worldview. This view of the morality of the market was, of course, contested by Marx (1990), who saw the class basis of the production process, and the violence required to generate surplus value, and later Keynes (1965) who wanted to put the market to work for the good of everybody in the name of a more equal society. But the apparent failure of this social democratic approach that dominated from the great depression through to the 1970s, which saw the emergence of a kind of flat line economy defined by low growth, high unemployment, and inflation, brought the moral vision of the superiority of the efficient market relative to the bloated state back into focus. According to Hayek (2001), the problem with the Keynesian state was that it spent too much and essentially discouraged saving meaning that the cost of private lending became prohibitive. As interest rates increased investment levels decreased with the result that economic growth slowed, unemployment rates began to climb, and the global economy continued to slide towards recession. In the face of this situation the neoliberal response was to cut back state spending, privatize industry, and deregulate labor in order to cut costs and create a more competitive market situation. While this approach offered an economic response to Keynes, it centrally also worked on the basis of a moral critique of the dependent, infantilized, statist man who needed to be freed from the shackles of big government in order to fully realize his liberty. In the wake of this turn towards a political philosophy of anti-statist individualism the politics of class conflict were sidelined and became more or less redundant in the period following the end of cold war, the fall of the Berlin Wall, the collapse of the Soviet Union, Deng's market reforms in China, and the emergence of the American-led end of history narrative. From the late 1980s onwards a fusion of Chicago style economics, or what Foucault (2008) called anarcho-capitalism, and German ordoliberalism, which seeks to manage and enable the free market, has dominated the global scene. It is in the context of this social, political, economic, and cultural condition, the subsequent history of neoliberal reform, and centrally high speed, high tech financialization that the crash occurred, the crisis unfolded, and austerity has been imposed across Europe. In the next section of the article I intend the explore the psychopolitics of austerity in the European, and specifically, British context in order to suggest reasons why this approach to economic management has found mass appeal and in some cases increased support for right wing parties committed to welfare and public sector cuts.

\section{| II. Thanatonomics and the Spectre of Neoliberalism}

While there has been a critical response to harsh austerity measures across Europe, and in particular in countries such as Greece, Spain, and Italy, I would suggest that this has been less apparent in Britain, where protest has been 
overshadowed by a post-political moral vision accepting of the "tough love" of austerity that ultimately swept Cameron, Osborne, and the Conservative architects of the cuts agenda back into office in 2015. In this section of the article I want to examine the psycho-politics and cultural reception of austerity in Britain, especially under conditions of neoliberal capitalism's celebration of excess and luxury. My objective in this discussion is to explore the appeal of austerity and seek to understand how first, the Conservative-Liberal Democrat Coalition and second, the current Conservative government have been able to defend the idea of austerity and gain support for a program of public sector cuts in a social context defined by class division, where widespread hardship, poverty, and misery very clearly rub up against extreme, excessive, ostentatious, and very conspicuous levels of consumption in particular sectors of society. My core thesis here is that the British appetite for austerity, despite the persistence of excess and luxury, is organized around a psycho-political moral desire for the austere life rooted in a response to the neoliberal principle of competition. While this economic principle is constructed in purely logical terms, so that competition ensures cost effectiveness, in practice the idea of capitalist struggle moralizes around the protestant, puritan, division between the categories of the saved and damned outlined by Weber (2010) in his The Protestant Ethic and the Spirit of Capitalism. According to this logic, where I ensure my own salvation through capitalist success, the punishment of the other who is damned by austerity makes political sense because their destruction makes my salvation more likely. On the other side of this equation, there is also a sense in which austerity culture satisfies the kind of thanatological drive to escape the self set out by Freud (2003b) in his Beyond the Pleasure Principle. In this classic work the founder of psychoanalysis explains that the oedipal self desires escape from the pain of individuation in a thanatological replay of the peace of life in utero. Underneath its commitment to cold, hard, instrumental reason I would suggest that the contemporary neoliberal economy pushes in this direction through on the one hand, flight into the thingness of absolute luxury, and on the other hand, the austere reduction of human life to its absolute base materialism - in both instances we confront the body that exists, but little more. Given this psychological condition, and the ways it has been made manifest in the neoliberal economy of extreme wealth and poverty, luxury and austerity, it is possible to see how the drive to compete, and moralize the destruction of the other in unsustainable levels of austerity which threatens their very existence, represents the sadistic projection or the other side of the basic masochism where I desire my own austere escape from the world of individuation, endless desire, and the suffocating blizzard of things that has come to define neoliberal consumer culture.

On the basis of the above psycho-political analysis we might suggest that the appeal of, and indeed desire for austerity, in Britain can be understood in terms of the political tradition of liberalism, and its suspicion of the state, and also British theological history, centered around Protestantism and the thanatological dimensions of this belief system which revolve around the drive to escape from the meaningless of material things. Of course, the paradox of this drive to overcome materiality in the name of a transcendental position closer to God is that the true believer becomes base material through their austere life when they reject every form of luxury and artifice. There is no more than bare metabolism in this view, which is, ironically, perfectly symmetrical with the neoliberal tendency towards instrumental rationality, economic metaphysics, and the theology of the bottom line. This shift from bare materiality, where economic metabolism is everything, to pure theological idealism, or spirituality is ensured by the dialectical reversal that takes place when the state of base materialism is realized which is precisely what Martin Luther understood in his original critique of Catholic ostentation. Ironically, base materialism, and closeness to death, opens up a direct line to the ideal, theological, universe of God. However, what the contemporary neoliberal political economic situation in Britain shows is that the Catholic approach to communion with God through fine things is equally operative in the post-modern consumer society where the truth of the post-crash settlement is an acceptance of uneven austerity where extreme poverty mixes with excessive wealth and luxury. In the context of uneven austerity, the austere desire to escape materialism finds its complement in the equally extreme pursuit of luxury and fine things which has led London to become home to more billionaires than any other city in the world (Sunday Times Rich List, 2014). On the surface, the world of the super-rich seem be concerned with the obsessive pursuit of material finery and absolutely devoid of any ideal dimension, but I would suggest that it is precisely this extreme materialism and absolute form of luxury that cancels in the emergence of base, or absurd, thingness, which ironically opens out onto a transcendental or, in Freudian language, oceanic space.

Akin to the practice of extreme austerity, which has gripped Europe, and been more or less accepted in Britain by a population that has re-elected the architects of the society of the cut, primarily because of a psycho-political predisposition to pursue an austere life towards death, my view is that the British live with the super-rich and their extreme consumption and ostentatious displays of luxury because ultimately their pursuit of fine things aims at the same post-material, transcendental, quasi-theological conclusion. At this point it is important to emphasize that this 
drive is thanatological and quasi-theological because there is no sense in which this paradoxical drive to escape materialism through the material is in any sense religious or organized around an explicit religious ideology because Britain remains a largely secular society. On the contrary, I would suggest that this thanatological, quasitheological, dimension is a kind of unconscious left-over which exists within the British national psyche and has come to define the social and political receipt and general acceptance of neoliberal economics, extreme inequality, and uneven austerity where some suffer and struggle to sustain their existence and others wallow in extreme and absurd luxury. My view is, therefore, that it is possible to find a spirit of neoliberal capitalism hidden within this thanatological, quasi-theological dimension that explains how this form of economics, or what we might call thanatonomics, continues to attract popular support in countries such as Britain in the context of extreme levels of inequality which have become more or less banal and no longer worth speaking about.

I want to return to the banality of inequality and what I want to call the neoliberal resistance to social analysis later in my discussion, but I think it is worth emphasizing here that the value of the exploration of the spirit of neoliberal capitalism is that it has the potential to make sense of the problem of the apparent materiality, necessity, and post-political pragmatism of neoliberalism that conditions its economic realism and subsequently takes the ground of social and political critique. The problem with this realism for critical thinkers is, of course, that it enables the contemporary neoliberal elite to claim that their worldview is simply organized on the basis of economic rationality, that they have no partisan attachment to any political position beyond the one that seeks to organize fair and open competitive market relations, and that there is no real alternative to this position in a world where the more or less free market has been globalized. In many respects this view, which is outlined by Jamie Peck (2012) in his book, Constructions of Neoliberal Reason, has been largely accepted by the left that has bought into the story of the post-ideological, post-political, dimension of neoliberalism and has indeed started to follow the harsh, uneven, realism of the right and the capitalist elites. However, the problem with this acceptance is that it cuts off opposition, resistance, or alternatives before they have even been fully imagined with the result that the left becomes trapped within a state of self-imposed neoliberal reason, realism, and stupidity on the basis of what it mistakes for pure, instrumental, post-political rationality, simply because it can no longer identify the ideological roots of this form of capitalism. The reason this acceptance of hard economic reason, retreat towards self-imposed stupidity, and caution against the utopian imagination is a mistake is because what Peck calls neoliberal reason, and talks about in terms of a form of pragmatism, is not organized around a coherent political ideology which is it possible to oppose on the level of rational thought, but rather a deep unconscious, cultural, inheritance that operates through a form of psychopolitical moralism that passes itself off as common sense precisely because of its unconscious, unspoken, status.

My sense is that it is possible to identify the presence of this psycho-political, moral, deep structure through its very absence in the work of the key critics of neoliberal reason such as Peck. In his book there is no neoliberal ideology, but only a form of highly adaptable pragmatism. In Peck's view the core neoliberal idea, the free market, is never complete, but always in process, always under construction. In this respect the lack of a fully coherent neoliberal ideology is the very point of neoliberal ideology or what he calls neoliberal reason. However, the problem with this view is that its recognition of realism, pragmatism, and cognitive mobility entails a loss of coherence and in the end it is unclear what exactly animates or defines the neoliberal project in an overall sense. While Peck (2012) writes of neoliberal reason, my view is that we must look for the ur-principle of neoliberal capitalism in the unconscious, unreason, and the kind of thanatonomics that we find expressed in the contemporary political economy of on the one hand, austerity and deprivation, and on the other hand, luxury and excess, precisely because I think that the extreme materiality or objective necessity of the neoliberal project is what confirms its theological, ideal, or unreasonable basis. It is possible find a comparable argument in Joseph Vogl's (2014) work on the idealism of contemporary economy, The Specter of Capital, which exchanges Marx and Engels' (2008) famous line about the specter of communism for Don DeLillo's (2011) reference to the specter of capital which haunts the contemporary global financial system. For Vogl, capitalism has always been a spectral machine ever since Smith wrote about the invisible hand and imagined that some benevolent theological power oversaw the conversion of private vice into public benefit. Vogl calls the contemporary capitalist system an economic theodicy, or oikodicy to refer to the idea of God's management of the household economy, but where he falls short in his exploration of the role of God in the neoliberal global system is in his failure to examine the way this idea finds its place in the history of social and political thought and how this mode of thought emerged from a deeply religious cultural milieu - for example, Smith's own theological belief and particularly his early interest in Protestantism which led him to imagine his economic God in the first place. Again, the value of this connection that leads back of Locke's (2003) notion of God-given rights, and even further Hobbes' (2008) biblical idea of the leviathan, is to extend the theory of the pure 
materialism and pragmatism of neoliberalism into a recognition of its spectral dimensions and beyond this towards an understanding of the ways in which this spectrality functions in the unconscious of those who accept, consume, and desire austerity on the basis of its promise of thanatonomic salvation.

Understanding this thanatonomic identification is especially pertinent in the British case under consideration because of the historical position of the home of capitalism caught between the origins of the liberal tradition of Hobbes (2008), Locke (2003), and Smith (2012) and the birth of anti-capitalist resistance, class struggle, and modern communism in the works of Marx and Engels (2008). What recognition of this unconscious dimension explains is precisely how the liberal, laissez faire, position survived the long 20th century from the 1930s onwards and eventually came back by way of Chicago and Austria to take over in the 1970s and even more, endured the 2008 crash, crisis, and recession through the imposition of a new Victorianism upon the British population. However, I would suggest that exploration of the thanatonomic spirit which animates neoliberal capitalism is not simply a story of class defeat, but instead also opens up a space for thinking about the critical potential of this perspective where realization of the stupid materiality of, and unconscious drive behind, neoliberalism starts to haunt the economics of limitless desire and endless growth with the specter of its own limitation in a vision of a new kind of economics, what Georges Bataille (1991) called general economy. Here, the stupid medium par excellence, money, no longer commands humans who come to understand that economy is useful, but not fundamental or essential in itself, for the fair distribution of goods across people who are no longer torn asunder by the pain of individuation, but recognize each other outside of the Darwinian logic of savage competition.

Beyond Spencer's (2009) vision of the survival of the fittest, which the English Victorian thinker coined in his Principles of Biology and which really should be seen as a key principle for understanding the conduct of neoliberal social relations, Bataille's general economy stands outside of the economic second nature and presents the possibility for a new kind of humanism. Thus I want to suggest that neoliberal thanatonomics symbolizes the extreme outer limit of capitalism and less death in itself than the death of a particular form of neoliberal subjectivity wedded to the extreme materialism of austerity, luxury, and the violence of economic survivalism. Moreover, I think that it is precisely because the current phase of neoliberalism seems to offer little choice between an austere future on the very edge of survival and a life of absurd excess, ridiculous ostentation, and meaningless luxury that the general economy - which is socialistic and takes into account the needs of humanity and human being in the world rather than mutilated economic individuals who think in terms of the costs and benefits through the lens of the medium of money - ranges into view and suggests the utopian possibility of the trans-individual who is simultaneously made in and through their interactions with others and the world. But before it is possible to think about the emergence of Bataille's (1991) general economy, which would entail the end of the misery of austerity and the absurdity of luxury in a reasonable society organized around a recognition of the truth of trans-individualism and an economic principle of equality, it will be necessary to overcome the moral position that we find in Smith (2012) and Weber (2010) where the austere self is a superior type who deserves everything they achieve and retake the space of critical thought that neoliberalism has very effectively colonized. In the case of Weber's work on the protestant ethic the psychology of the austere capitalist, who saves and reinvests rather than spends and wastes, is taken to be evidence of this type's moral superiority and this vision is employed in contemporary discourse around the deserving super-rich who somehow earn their money. From this point of view it is ironically the super-rich, wallowing in luxury, who are truly living in austerity and the poor who are lazy, wasteful, and ultimately undeserving. However, it is very difficult to support the idea that the contemporary neoliberal elites embody this austere, moral, approach of selfhood, simply because of their commitment to thanatonomic consumption practices. On the contrary, in the contemporary British context the critique of waste and wastefulness and the harsh medicine of austerity has been clearly reserved for the weakest members of society, including the poor, children, and the disabled, who are considered in need of reform in order to make them more productive in a situation where welfare is a waste of money.

In light of this kind of political critique of the morality of contemporary austerity, and the ways it separates from what Weber had in mind, which becomes a justification for inequality on the basis that the economic elite are represented as morally superior, I believe that it is possible to exchange the liberal, moral, vision of what we might call the spirit of neoliberal capitalism for a critical perspective that takes in the violence, misery, and injustice inspired by economic relations in contemporary Britain. The effect of this transition from a position where morality justifies the injustice of superiority and inferiority, wealth and poverty, and the imposition of uneven austerity in the context of exorbitant luxury to a critical perspective which recognizes the violence of the contemporary social, political, economic, and cultural settlement is, in my view, to transform the spirit of neoliberal capitalism into its scary other, what I want to call the specter of neoliberalism, that haunts the unjust society and points towards the possibility 
of some other approach to social life beyond the extremes of wealth and poverty of thanatonomics. When the spirit of neoliberal capitalism, which names the energy, attitude, and disposition that drives this ideological form into the future, becomes the specter of the same economic form, the ghosts and ghouls of Marx and Engels' (2008) vision of communism that haunted Victorian capitalism come back onto the scene and it becomes clear that the thanatonomic system is unsustainable. The reason for this is that the 20th century model of distributed growth imagined by Keynes (1965), which sustained capitalism in the period stretching from the 1930s through the 1970s, has been exchanged for a kind of Victorian growth that is uneven, poorly distributed, and does very little to tackle the socially divisive problem of inequality. In this situation, where the twin infinitives of austerity and luxury become the key reference points of capitalism, economics become thanatonomics and there is no way to defer antagonism into the future. Antagonism is now and there is no escape from the kind of social war Foucault (2004) spoke about in his seminar Society Must be Defended and Virilio (2008) captures through his idea of pure war. In contemporary Britain the neoliberal elite's strategy has been to wage a more or less secret political war on the weakest in society and defend the 19th century vision of the moral spirit of capitalism. In this view the rich are deserving in spite of their very public excesses, while the poor are clearly sinful, lazy, wasteful, undeserving, even when their structural disadvantage is beyond doubt.

What this illustrates is that beyond the ideology of post-politics, which suggests that neoliberalism is a form of rationality, reason, and realism, contemporary capitalism is really based in a deeply violent political, moral, economy that separates the moral from the immoral, the useful from the useless, the deserving from the undeserving, and the normal from the pathological. But explicit recognition of this political strategy, which transforms the weakest members of society into human waste, would clearly be a serious strategic mistake for the elites so the post-political utilitarian explanation takes over and it appears that there is no alternative to the kind of banal, objective, violence that destroys lives in the name of the post-human, ordoliberal, lie of economic balance. But I would suggest that it is becoming increasingly difficult to defend the Weberian vision of moral capitalism today, or even pretend that austerity is somehow evenly distributed, because this is clearly a class based project that excludes those who wallow in luxury who are strangely everywhere but nowhere in popular and academic discourse. Given this view it may be that it is better to try to understand the truth of neoliberal capitalism, or at least the truth of the neoliberal capitalist elites, through Werner Sombart's (1967) work on the relationship between luxury and capitalism, which explains that the origins of capitalism reside in consumption, excess, and centrally sexual desire. On the basis of Sombart's reading on luxurious capitalism, which coincidentally emerged in the early 20th century when Freud was in the process of rethinking human psychology and the fundamental importance of the sex instinct, I think that it is possible to suggest that capitalism is essentially never about austerity, and reinvestment in the name of God, but rather its polar opposite - the potentially positive Freudian sex instinct or the transgressive, creative, power of Marx's notion of species being expressed economically. Although Sombart is rarely connected to neoliberal capitalism, which has fallen in love with the idea of a kind of economic realism or rationality that conveniently locates it in a post-political space, there is clearly a direct line from his work, and particularly books such as War and Capitalism, and the neoliberalism of, for example, Schumpeter (2010) who wrote about economic innovation, creative destruction, and the new that cannot be quantified, that suddenly shifts everything, and makes a difference that matters. In this respect I would suggest that it is a mistake to accept the thinly veiled moral politics of contemporary capitalism, which explain that there is no alternative to the necessity of economic realism and the rejection of wastefulness, excess, and change, because neoliberal economics are themselves based in the idea that excess is what drives capitalism forward and opens a space onto the emergence of the new that is essential to the idea of modernity itself.

But what Schumpeter (2010) or the other early neoliberals could not have foreseen or explored in their works where they opposed the freedom of entrepreneurialism to the bureaucratic tyranny and in some cases the outright totalitarianism of the state, was that the late capitalist neoliberal state would itself become the champion of a kind of economic totalitarianism organized around a brutally efficient, highly organized, system for the production of surplus value which leaves very little room for individual freedom in general. Of course, individual freedom remains on the scene, because the contemporary thanatonomic system ensures some live lives characterized by a kind of hyper-individualism and hyper-freedom that threatens to cancel itself in its very lack of opposition, but there is little sense that this is in any way distributed through the social system precisely because the majority, and especially those deemed undeserving, worthless, and useless, must live under conditions of strict austerity which limits their ability to realize their formal freedom and even more, very consciously throws them into a state of nature where they must struggle to survive. Beyond the early 20th century pair of Weber (2010) and Sombart (1967), who capture the polar opposites of the austere and excessive capitalist modes of subjectivity, there is a sense in which it is possible 
to find the same tension in the works of three contemporary thinkers who have explored the idea of the spirit of capitalism, Luc Boltanski and Eve Chiapello and Bernard Stiegler. In their work on the new spirit of capitalism, Boltanski and Chiapello (2006) show how neoliberalism capitalism emerged from the Keynesian settlement on the basis of a fear of the totalitarian state and its impacts upon individual freedom. For Boltanski and Chiapello the Keynesian state eventually responded to the general fear of totalitarianism, which found expression in events such as May 1968, by adopting a new stance on capitalism and market forces that eventually led to the emergence of the new creative capitalism. In this respect Boltanski and Chiapello update Sombart's story, where capitalism is organized around its ability to harness, what we might call in Freudian terms, libidinal energy in order to produce innovation, development, and growth. However, the problem with this story is that it is incomplete because what we see in contemporary capitalism is the way in which this freedom of desire and expression is unevenly distributed through relations of production which ensure that some enjoy the freedom of what I have called above, hyper-individualism, and others are constrained by the limits of austerity and state imposed austere subjectivity. This is the work of the new leviathan, the neo-totalitarian, neoliberal, iron cage.

Where Boltanski and Chiapello's story is incomplete, therefore, is in its failure to recognize the other side of the neoliberal turn to individual freedom and away from state restriction. While the neoliberal turn reflected a shift in economic policy, and a move away from welfare statism, towards an idea of the free, creative, entrepreneurial self, able to stand on their own two feet, it has also entailed the rise of a biopolitical punitive security state organized to police others and ensure that their behavior follows the new individualistic regime of truth where the moral politics of austere subjectivity applies to those who are not in a position to buy exemption from its constraints. This is precisely what I would suggest a reading of Bernard Stiegler's (2011, 2012, 2014) work on decadence, disbelief, and discredit can explain. In Stiegler's work the neoliberal turn to economic individualism, which has translated the economics of desire, where I must wait for what I want, into the thanatonomics of drive, which entails the collapse of the period of deferral into a dense moment of meaningless satisfaction and despair where I want for nothing but also lose my reason for living, has led the state to move from an institution concerned with welfare to one organized around the need to police the fallout from the turn to thanatonomics. At this point it is important to understand the psychoanalysis of the emergence of thanatonomics because this enables recognition of the profound nature of this fall out. In Stiegler's view the general problem with the end of the modern period of the deferral of desire, which results from an economic system that says "you may have what you want now," even if this involves taking out unsustainable credit, is that the entire symbolic order or cultural system which sustains subjectivity within a framework of norms, regulations, and prohibitions that limit and centrally enable civilized behavior starts to break down. For Stiegler, the result of this breakdown is the emergence of a new kind of society, where there is no future because the very idea of the future relies on a notion of deferral organized through symbolic structures of prohibition and proscription, which represents the social-psychological dimension of Fukuyama's (1992) vision of the geo-political end of history.

Living through the end of history, Stiegler's $(2011,2012,2014)$ de-subjectified subject, who we can only call a subject negatively because the rules this new person obeys are rules about the end of limits, is the fleshed out psychoanalytic explanation of Fukuyama's last man. While true freedom resides in an appreciation of limits, the last man's freedom no longer recognizes prohibition. In this respect his freedom is properly thanatonomic in that it revolves around a utopian, but also centrally dystopian, sense of the end of the future that means that nothing is possible, in the sense that meaningful change has become impossible, but everything is permitted, since there is no prohibition on behavior that assumes its own meaninglessness. It is under these economic conditions, which have resulted in the collapse of normal, oedipal, subjectivity where individuals recognize limits, that the state has adopted a new role centered around neo-totalitarian bio-political control. In the Keynesian period from the end of World War II to the late 1970 s this was never necessary because subjective limits could be assumed and the state could encourage spending in order to stimulate growth and centrally redistribution across society. However, under conditions of neoliberalism, where the subject has been fully emancipated from the very constraints that once defined its identity, there is no need to encourage spending, because the new de-subjectified subject will consume until its very end, and redistribution makes no sense because the wider social, symbolic, cultural structures that made the idea of a society matter no longer hold. In this situation, the only possible function for the state in the wake of crash, which was the result of the madness of the financial elites who behaved with complete de-subjectified abandon, is to maintain some kind of order within the parameters of the neoliberal thanatonomic system, where people are entirely free of social responsibility. This means that there is no real recognition of moral or social responsibility for the crash, but only a class based discourse that explains that the problem resides, and has always resided in the exorbitant cost of 
the social structures that make it possible to understand morality and responsibility in the first place.

In the context of the neoliberal ideological framework that no longer recognizes social responsibility, but is on the contrary allergic to the very suggestion of social interdependence, the moralism that emerged in the wake of the crash was never about over-consumption in itself, but rather reliance on the social, welfare, state. This is why austerity, and the project to reconstruct an austere self, is colored by neoliberal extremism, and thanatonomics, in that the drive to restrict the new self is in a sense unrestricted, and excessive in that it assumes that limits are potentially limitless. Since there are no prohibitions on how far the austere individual can be pushed in the name of the reduction of their material burden on others, the drive to austerity becomes a quasi-theological project in that its opposition to material costs eventually lapses into a kind of transcendental idealism, or vision of mystical perfection, where everything becomes perfectly symmetrical, but also, most importantly, subsumed in everything else. It is precisely here, at the extreme edge of neoliberal economics, or what I have sought to call thanatonomics, that I think we enter the space of Bataille's general economics beyond neoliberal moralism. While Bataille's central focus in his key work on general economy, The Accursed Share (1991), is luxury, and the ways in which the luxurious transgresses the material for a kind of transcendental, oceanic, space, I would argue that historically, and in the contemporary politics of austerity, the austere aims at the same target, which is the escape from the banal world of things for a more meaningful universe which recognizes the profound interaction between everybody and everything.

However, it is, paradoxically, precisely this universe, the universe of the general economy that contemporary neoliberalism seeks to deny through first, its obsession with the meaninglessness of restricted economic realism, rationalism, and pragmatism, and second, its insistence on both methodological and moral individualism, where the individual is practically limited in terms of what they can know, the rights they can claim, and responsibilities they are expected to fulfil. But it is essentially because of this desperate denial of general economics in the name of restricted economics, particularly in a period where the ecology of human and world has become clear, that it has become impossible to ignore the general economic truth that interactions between humans cannot be reduced to the basic exchange of money. That is to say that the barely contained truth of the contemporary neoliberal condition, which has been repressed in the symptomatic emergence of a horrendous situation where some live in absolute luxury and others struggle to survive in a state of austerity that makes life scarcely livable, is that the human condition is defined by what Gilbert Simondon (Combes, 2012) called trans-individualism, that this state of radical interdependence stretches back across the generations to define our past, present, and possible futures, and that it is impossible to live without the debt that contemporary economics seeks to deny, but which is in reality, a necessity of existence itself. Given that it is impossible for the individual to ever repay their debt to others and the world itself, simply because credit and debt define existence which is always in a state of becoming, it may be the case that neoliberalism represents the most naive, unrealistic, and unreasonable economic form it is possible to imagine. If this is the case, perhaps the origins of this mode of thinking are less concerned with pragmatism, and more bound up with the ancient, tragic, tradition where the individual refuses their relationship to the world in the name of the escape from necessity into the realm of the Gods. In light of this perhaps it is the tragic wisdom of the ancients that has been lost in the rebellious hubris of neoliberal capitalism that imagines the utopian individual out on his own beyond relations to others and world. Perhaps it is this hubris, and this desperate belief in the omnipotence of the capitalist individual, that the left needs to correct today by exploding the myth that denies the necessity of interdependence of self, other, and world. In the final section of this article I want to conclude in an exploration of what I want to call the resistance to social analysis which I would suggest has come to define the neoliberal period and resulted in the foreclosure of this general economic truth. My argument here is that it is possible to trace this refusal of social, or to use Simondon's term trans-individual, truth back to the origins of liberalism, and then later, neoliberalism and that these points represent traumatic moments, and potentially social, political, economic, and cultural catastrophes, which we must work through in the proper psychoanalytic significance of the idea of "working through" in order to make the leap beyond contemporary thanatonomics into the sustainable world of general economics where the relation of self, other, and world is understood as necessary and irreducible.

\section{The Trauma of Neo/Liberalism}

In order to move beyond the twin infinitives of austerity and luxury, which have come to define neoliberal thanatonomics and the common sense market fundamentalism that makes extreme inequality appear acceptable, 
my view is that the left must look to oppose what I want to call the resistance to social analysis that comprises the contemporary post-political milieu where economic violence is understood in terms of realism, rationalism, and pragmatism and any sense of social responsibility is considered leftist or Marxist madness. In the most basic sense I would suggest that this resistance to social thought, analysis, and critique finds its basis in the rise of individualism, the collapse of the mainstream left in countries such as Britain, and more profoundly the failure of the very social, symbolic, cultural structures that make sociological understandings possible. In this context my use of the idea of the resistance to social analysis has very particular significance which relates to the psychoanalytic notion of the resistance to psychoanalysis that explains that analysands will tend to resist psychoanalysis, and centrally psychoanalytic truths, precisely because these threaten to unearth repressed, traumatic, contents that the subject cannot accept because these will undermine the very basis of their subjectivity (Freud, 2003a). Thus the subject of psychoanalysis will tend to find psychoanalytic truths absolutely untrue and absolutely ridiculous precisely because these repressed contents represent the very negative foundations of their subjectivity. Given this theory, my thesis is that it is possible to find a similar, social and political form of resistance to critique inherent in the contemporary neoliberal postpolitical commitment to economic reason and that it is this resistance that the left must oppose or resist if it is to ever construct a viable politics committed to social equality and justice that does not crash upon the rocks of the neoliberal idea of hard economic rationality. In psychoanalysis resistance to analysis represents a defense mechanism against traumatic contents that must be first, uncovered and second, worked through in order to enable the subject to accept its past and centrally move forward into the future free of the endless repetitious effort to resolve the unbearable traumas that are already lost to its past. Regarding the contemporary social and political problem of neoliberalism, and its deep resistance to social analysis that has come to infect the social body that accepts hyperdivision and hyper-inequality, my view is that it is possible to identify two key traumatic moments, relating to first, the modern break with the ancients, and second, the post-modern break with the moderns, which must be worked through in order to open out onto a kind of post-post-modern space beyond the capitalist fantasy of the completely independent man from nowhere.

In the first instance I want to suggest that it is possible to turn to the modern father of austerity, John Locke, and particularly his discovery of the world as private property. Here, my suggestion is that Locke's (2003) philosophical innovation around private property represented a traumatic moment in social, political, and economic history on the basis that what he achieved was a radical break from the ancient theory of the relationship between man and world where the human attempt to escape from the environment had always been thought through in terms of tragedy and failure. Against this tragic vision which we find everywhere in the ancient world, Locke took seriously the possibility of man's escape from the world that subsequently becomes his property. Once this initial break had taken place, and the world had been transformed into an economic object, it was also possible for man to take himself for his own property, and the other as a potentially dangerous stranger who could threaten this form of possessive individualism. Thus the state emerges in order to defend man's right to own himself and the world from others who may seek to infringe these rights. Of course, from Marx's (1988) point of view, this freedom is no freedom worthy of the name, but rather represents the alienation of humanity from self, other, and world that comprise our essential species being. Despite this early philosophical critique which we find in Marx's 1848 Manuscripts, unfortunately what the left managed to oppose in the new capitalist system was the material inequality between people, and it is this that Keynes (1965) managed to address in his theory of the state management of the economy. While Smith (2012) sought to place the burden of ethical responsibility onto the benevolent invisible hand, Keynes saw that the state must manage economy and produce growth in order to emancipate people from need and create a situation where it would be possible to live outside of the necessity of money. Although the leftist response to the original modern liberal break with the ancients was, therefore, concerned to address the problem of inequality, I would suggest that it failed to respond to the original traumatic event, which saw self, other, the world torn asunder and transformed into independent economic actors who then need to be made equal. It was only on the basis of the persistence of this condition of estrangement which resulted from the original trauma that Hayek and the neoliberals were able to respond to the threat of what they saw as the totalitarianism implicit in Keynesianism and eventually produce what I would suggest represented the post-modern trauma of neoliberalism that further emancipated the self from other and destroyed any sense of community and social responsibility in a new consumer society where the individual is thought to be absolutely self-contained and beyond the influence of self and world.

In the British case, this post-modern situation has been operative from Margaret Thatcher's period in office, through the Blair / Brown New Labour years, and the current Cameron / May era of harsh cuts and austerity. While Thatcher sought to emancipate the self from community, and in particular destroy the working class sense of social 
responsibility and unionism which had become a break on profitability, the Blair / Brown period of government was defined by what Anthony Giddens (1998) called the third way, which named the attempt to reconcile rampant individualism with social welfare, and the catastrophic market crash of 2008. It is this situation that Cameron inherited first, in office with the Liberal Democrats and second, in the current Conservative government, and has sought to resolve through the destruction of the welfare state through austerity. As such, Cameron sought to reconstruct the minimal state imagined by Locke, which was only ever necessary to protect private property, and recreate a Victorian style class system, where the poor must struggle to survive and the rich are free to consume without limits, on the basis this that is morally right inside the neoliberal universe where the truth of sociability is repressed. However, in much the same way that the system that emerged from Locke's (2003) work on private property, the 19th century version of laissez faire capitalism, produced Marx's (1988) philosophical critique of estrangement and the mutilation of humanity, my view is that the polar opposition of contemporary neoliberal society defined by what I have called the thanatonomics of austerity and luxury will eventually produce a new idealism, or transcendental materialism, organized around recognition of the interdependence of self, other, and world. I have sought to explain this shift in thought, which essentially describes the telescoping of post-modern and ancient philosophy, through reference to Georges Bataille's work, The Accursed Share (1991), and his theory of the general economy where estrangement collapses into a new state of intimacy and what he calls continuous being. Although this new economics will have to struggle against the contemporary neoliberal resistance to social analysis, which is set on the maintenance of the status quo, my sense is that this deeply repressive approach to the defense of the idea of the free floating individual will not be able to survive the austere future that condemns some to barely livable lives and others to excessive, meaningless, luxury, because extreme levels of inequality will generate the spectral other of this system, the specter of neoliberalism. In the face of this unsustainable situation that rejects the necessary relationship of self, other, and world, the specter of neoliberalism, or perhaps more precisely the specter of the end of neoliberalism, that haunts the social, political, and economic system will eventually mean that there is no choice but to confront and work through the historical traumas of modern and post-modern capitalism.

\section{References}

Bataille, G. (1991) The Accursed Share: Volume I: Consumption. New York: Zone Books.

Blyth, M. (2013) Austerity: The History of a Dangerous Idea. New York: Oxford University Press.

Boltanski, L. and Chiapello, E. (2006) The New Spirit of Capitalism. London: Verso.

Combes, M. (2012) Gilbert Simondon and the Philosophy of the Transindividual. Cambridge, Mass: MIT Press.

DeLillo, D. (2011) Cosmopolis. New York: Picador.

Disraeli, B. (2008) Sybil: Or the Two Nations. Oxford: Oxford University Press.

Foucault, M. (2004) Society Must be Defended: Lectures at the College de France - 1975-1976. London: Penguin.

Foucault, M. (2008) The Birth of Biopolitics: Lectures at the College de France - 1978-1979. Basingstoke, Hampshire: Palgrave.

Freud, S. (2003a) An Outline of Psychoanalysis. London: Penguin.
Freud, S. (2003b) Beyond the Pleasure Principle: And Other Writings. London: Penguin.

Fukuyama, F. (1992) The End of History and the Last Man. London: Penguin.

Giddens, A. (1998) The Third Way: The Renewal of Social Democracy. Cambridge: Polity.

Hayek, F. (2001) The Road to Serfdom. London: Routledge.

Hobbes, T. (2008) Leviathan. Oxford: Oxford University Press.

Keynes, J. M. (1965) The General Theory of Employment, Interest, and Money. New York: Harcourt.

Klein, N. (2007) The Shock Doctrine: The Rise of Disaster Capitalism. New York: Metropolitan Books.

Locke, J. (2003) Two Treatises of Government and a Letter Concerning Toleration. New Haven: Yale University Press.

Mandeville, B. (1989) The Fable of the Bees: Or Private Vices, Publick Benefits. London: Penguin.

Marx, K. (1990) Capital: Critique of Political Economy: Volume I. London: Penguin. 
Marx, K. 'Estranged Labour' in Economic and Philosophic Manuscripts of 1848 and The Communist Manifesto. Marx, K. and Engels, F. (1988). New York: Prometheus Books. Pg. 69-85.

Marx, K. and Engels, F. (2008) The Communist Manifesto. Oxford: Oxford University Press.

Peck, J. (2012) Constructions of Neoliberal Reason. Oxford: Oxford University Press.

Schui, F. (2014) Austerity: The Great Failure. New Haven: Yale University Press.

Schumpeter, J. (2010) Capitalism, Socialism, and Democracy. London: Routledge.

Smith, A. (2010) The Theory of Moral Sentiments. London: Penguin.

Smith, A. (2012) The Wealth of Nations. Ware, Hertfordshire: Wordsworth.

Sombart, W. (1967) Luxury and Capitalism. Ann Arbor, MI: University of Michigan Press.
Spencer, H. (2009) The Principles of Biology: Volume I. Ithaca, NY: Cornell University Library.

Stiegler, B. (2011) The Decadence of Industrial Democracies: Disbelief and Discredit: Volume I. Cambridge: Polity Press.

Stiegler, B. (2012) Uncontrollable Societies of Disaffected Individuals: Disbelief and Discredit: Volume II. Cambridge: Polity Press.

Stiegler, B. (2014) The Lost Spirit of Capitalism: Disbelief and Discredit: Volume III. Cambridge: Polity Press.

Virilio, P. (2008) Pure War. New York: Semiotext(e).

Vogl, J. (2014) The Specter of Capital. Stanford, CA: Stanford University Press.

Weber, M. (2010) The Protestant Ethic and the Spirit of Capitalism. Oxford: Oxford University Press. 
